\title{
Adoption of Urea Deep Placement Recommended Practices among Rice Farmers in Niger State, Nigeria
}

\author{
*Ajibola B.O., Fatoki P.
}

Department of Agricultural Economics and Extension Technology, Federal University of Technology, Minna, Nigeria

\begin{abstract}
This study assessed the factors influencing adoption of UDP recommended practices by rice farmers in Niger State, Nigeria. A total of 86 rice farmers were selected for the study using multi-stage sampling procedure. Structured questionnaire was used for data collection. Descriptive statistics and multiple regressions were used for data analysis. Results revealed that majority (60.5\%) of the rice farmers were male and the respondents' mean age was 49 years. The mean household size was 7 people while less than half (48.9\%) of the respondents had no formal education. The average farm size cultivated by the rice farmers was $0.8 \mathrm{ha}$ and all $(100.0 \%)$ the respondents had no access to credit facilitates2015/2016 cropping season. The significant variables were sex, education, rice farming experience, farm size, paddy output, training and complexity. Constraints hindering adoption of UDP recommended practices were lack of credit facilities, labourious nature of line transplanting and USG application as well as limited USG supply, time spent on application of USG, inadequate training and health status of the rice farmers. It was recommended that government should ensure that credit facilities are made available and accessible to rice farmers in the study area. Also, trainings on UDP recommended practices should be a focal point for the government, non-governmental organizations and private sector actors to deal with the inadequate knowledge of UDP recommended practices among the rice farmers.
\end{abstract}

Keywords- adoption, urea deep placement (UDP) recommended practices, rice farmers, Niger State.

\section{INTRODUCTION}

Urea is the most widely used source of Nitrogen $(\mathrm{N})$ fertilizer globally including Nigeria, both for irrigated and rain-fed rice cultivation. Nitrogen $(\mathrm{N})$ use efficiency in rice production which is expected to increase yield can be achieved by the adoption of UDP recommended practices by rice farmers. Field demonstrations in several sites across Africa and Asia have indicated significant potential benefits of the UDP technology (IFDC, 2011) and (IFDC, 2013). IFDC promoted
UDP technology adoption in Benin, Burkina Faso, Mali, Niger, Nigeria, Senegal and Togo to increase paddy grain yield and nutrient efficiency (IFDC, 2011)

According to IFDC (2012), UDP technology consists of two key components. The first is a fertilizer 'briquette' produced by compacting commercially available urea fertilizer (e.g., which is then known as Urea Super Granules (USG) weighing roughly 1-3 grams per briquette). The second key component of UDP is the placement of urea briquettes (USG) below the soil surface. When used to fertilize irrigated rice, the briquettes are centred between four plants at a depth of 7-10 centimetres within seven days after transplanting. Placement can be done either by hand or with a mechanical applicator.

USG is said to increase nitrogen use efficiency on rice fields because more urea nitrogen stays in the soil, close to the plant roots where it is absorbed more effectively (Adjornon and Liverpool-Tasie, 2014), thereby reducing greenhouse gas (GHG) emissions. In addition, the environment is protected as urea fertilizer broadcasting under the ordinary application, leach into streams and rivers rendering it unfriendly to the environment. The application of USG gradually releases Nitrogen $(\mathrm{N})$ gradually in to the soli, thereby coinciding with rice crop's requirements during the growing season (IFDC, 2012). In this production process $\mathrm{N}$ fertilizer is required to be applied only once for the entire crop season unlike the conventional urea production process when 3-4 applications are required (mainly broadcasting first and then top-dressing subsequently).

Small granular urea is the most commonly used nitrogenous fertilizer for rice cultivation in Nigeria. In view of the fact that rice farmers yield is directly related to efficient use of urea fertilizer, the federal government of Nigeria through Federal Ministry of Agriculture and Rural Development (FMARD), Notore Chemical Industries Limited, IFDC and Maximizing Agricultural Revenue and Key Enterprises in Targeted Sites II (MARKETS II), a USAID funded project began collaborating on expanding the supply and demand of USG in targeted Nigerian rice production regions since 2012 (Tarfa and Kiger, 
2013). Likewise, FMARD approved the introduction of USG fertilizers as one of the agro-inputs distributed under the 2014 Growth Enhancement Support Scheme (GESS), in Niger, Kano, Kebbi, Jigawa, and Sokoto States on a pilot base (Fertilizer Suppliers Association of Nigeria (FEPSAN, 2014). The introduction of the USG into the GES scheme was aimed at increasing the adoption of UDP technology among rice farmers in the selected States.

Despite these interventions on UDP technology, adoption of recommended practices by rice farmers in Niger State is low. Studies carried out to examine the factors influencing adoption of UDP recommended practices are inadequate and very scanty in Niger State. The broad objective of the study is to examine the adoption of UDP recommended practices among rice farmers in Nigeria State, Nigeria. The specific objectives were to describe the socio-economic characteristics of rice farmers in the study area; determine the factors influencing the adoption of UDP recommended practices among the rice farmers, and identify constraints limiting adoption of UDP recommended practices among respondents. This study hypothesized that there is no significant relationship between the rice farmers' socio-economic characteristics and the adoption of UDP recommended practices.

\section{METHODOLOGY}

The study was carried out in Niger State, the state falls in the guinea savannah zone and has a climate and ecological conditions that favors agricultural production. It has an annual rainfall of between $1100 \mathrm{~mm}-1600 \mathrm{~mm}$ and has an average temperature of $35^{\circ} \mathrm{C}$ (Koloche et al., 2016; Gbako, 1991). Based on the 2006 National Population Census, the state has a total population of 4,250,429 in 2006. The majority tribes are Nupe, Gwari, Hausa and Kambari with about $85 \%$ of this population practicing agriculture specifically, growing rice, sorghum, cowpea, yam and maize in large quantity.

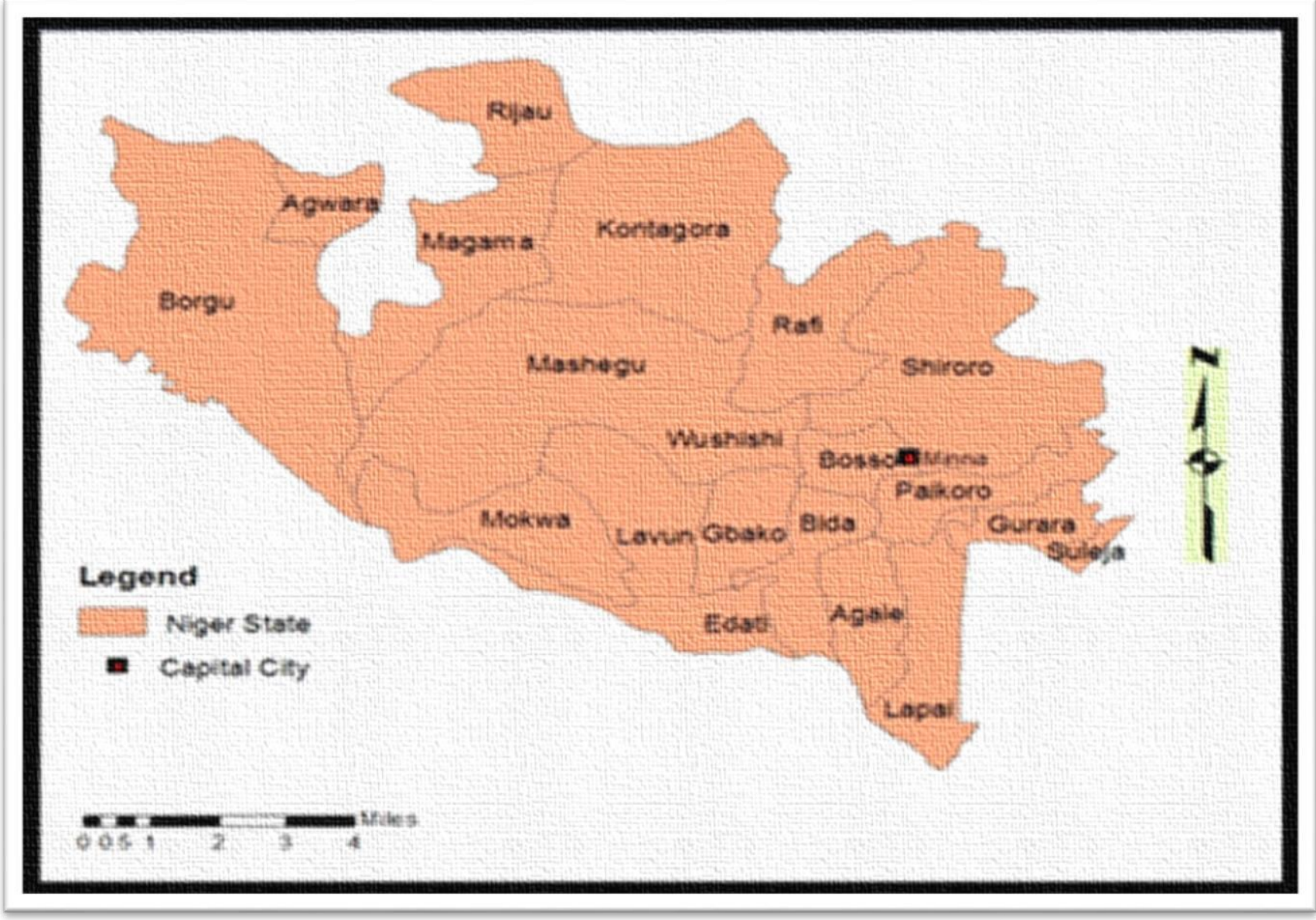

Fig.1: Map of Niger State

The target population for this study included of rice farmers registered under the MARKETS II Project in Niger State.
Multi-stage sampling procedure was used to draw samples for the study. The first stage involved a purposive sampling 
of all the intervention local government areas (LGAs) in the State as follows: Bida, Edati, Gbako, Lavun and Wushishi. This was followed by random selection of networked cooperative societies from the participating LGAs using a proportionate sampling technique, thus given 76 cooperative societies were selected from 228 cooperative societies. Lastly, since membership of the cooperative societies was not the same a proportionate sampling technique was also applied to randomly select the rice farmers, hence; a total 86 rice farmers were selected for this study.

A well-structured questionnaire was used to collect primary data for the study. Enumerators were used to administer the questionnaire to the rice farmers. Both descriptive and inferential statistics were employed in data analysis. Objectives $i$ and iii were achieved using descriptive statistics which included frequency distribution, percentage and ranking while multiple regression analysis was used for objective ii. Multiple regression was also used to test the stated hypothesis. The functional form is expressed in the explicit form below.

$\mathrm{Y}=\mathrm{a}+\mathrm{b}_{1} \mathrm{X}_{1}+\mathrm{b}_{2} \mathrm{X} 2+\mathrm{b}_{3} \mathrm{X}_{3} \ldots \ldots \ldots \ldots \ldots \ldots \mathrm{b}_{14} \mathrm{X}_{14}+\mathrm{U}$

Where:

$\mathrm{Y}=$ Adoption of UDP technology (UDPT)

$\mathrm{X}_{1}=\operatorname{Sex}($ male $=1$, female $=0)$

$\mathrm{X}_{2}=$ Farmers age (years)

$\mathrm{X}_{3}=$ Household size (number)

$\mathrm{X}_{4}=$ Education (years)

$\mathrm{X}_{5}=$ Rice farming experience (years)

$\mathrm{X}_{6}=$ Extension agents visit $(\mathrm{Yes}=1, \mathrm{No}=0)$

$\mathrm{X}_{7}=$ Access to credit $(\mathrm{Yes}=1, \mathrm{No}=0)$

$\mathrm{X}_{8}=$ Rice farm size (hectares)

$\mathrm{X}_{9}=$ Paddy output $(\mathrm{Kg})$

$\mathrm{X}_{10}=\mathrm{USG}$ source (number of sources)

$\mathrm{X}_{11}=$ Training (number of trainings received)
$\mathrm{X}_{12}$ = Affordability of UDP technology (Expensive to use $=1$, Otherwise $=0$ )

$\mathrm{X}_{13}=$ Compatibility of UDP technology (Meet needs with existing values $=1$, Otherwise $=0$ )

$\mathrm{X}_{14}=$ Complexity of UDP technology (Difficult to use $=1$, Otherwise $=0$ )

$b_{1}-b_{14}=$ Regression coefficient

$\mathrm{a}=$ constant term

$\mathrm{X}_{1}-\mathrm{X}_{14}=$ Independent variables

$\mathrm{U}=$ error term

\section{RESULTS AND DISCUSSIONS}

Table 1 shows that majority $(60.5 \%)$ of the rice farmers were males. This is consistent with the findings Chekene and Chancellor (2015) who found that majority of rice farmers in Borno State, Nigeria were males. Also, the average age of the sampled farmers was 49 years. This implies that majority of the sampled farmers were within the active productive ages. This means that rice farmers are physically fit and mentally alert to embrace new techniques of rice production, such as UDP recommended practices. This agrees with Jamiu et al., (2016) that the average age of rice farmers was estimated to be between 40 and 49 years in Kogi State, Nigeria.

It was further found in Table 1 that the average household size of the farmers was 7 persons. This implies that rice farmers in the area have considerable family, labour thereby reducing the cost of labour needed in adopting UDP recommended practices prescribed practices. The average rice farming experience in the area was 30 years. This implies that the respondents had long years of rice farming experience. Long farming experience is an advantage for increased rice production since it may encourage rapid adoption of improved rice recommended practices (Onyeneke, 2017). 
Table.1: Distribution of respondents on socio-economic variables

\begin{tabular}{|c|c|c|}
\hline Variables & Niger State $(n=86)$ & Mean \\
\hline \multicolumn{3}{|l|}{ Sex } \\
\hline Male & $52(60.5)$ & \\
\hline Female & $34(39.5)$ & \\
\hline \multicolumn{3}{|l|}{ Age (years) } \\
\hline $20-30$ & $1(1.2)$ & 49 \\
\hline $31-40$ & $7(8.1)$ & \\
\hline $41-50$ & $49(57.0)$ & \\
\hline $51-60$ & $23(26.7)$ & \\
\hline$>60$ & $6(7.0)$ & \\
\hline \multicolumn{3}{|l|}{ Household size } \\
\hline $1-5$ & $4(4.7)$ & 7 \\
\hline $6-10$ & $11(12.8)$ & \\
\hline $11-15$ & $71(82.6)$ & \\
\hline $16-20$ & - & \\
\hline \multicolumn{3}{|l|}{ Educational level } \\
\hline No formal education & $25(29.1)$ & \\
\hline Adult education & $11(12.8)$ & \\
\hline Quranic education & $6(7.0)$ & \\
\hline Primary education & $34(39.5)$ & \\
\hline Secondary education & $10(11.6)$ & \\
\hline Tertiary education & - & \\
\hline \multicolumn{3}{|c|}{ Rice farming experience } \\
\hline $1-5$ years & - & 30 \\
\hline $6-10$ years & - & \\
\hline $11-15$ years & $4(4.7)$ & \\
\hline $16-20$ years & $24(27.9)$ & \\
\hline $21-25$ years & $11(12.8)$ & \\
\hline$>25$ years & $47(54.7)$ & \\
\hline \multicolumn{3}{|l|}{ Farm size } \\
\hline$<1.0 \mathrm{ha}$ & $70(81.4)$ & 0.8 \\
\hline $1.0-1.5 \mathrm{ha}$ & $6(7.0)$ & \\
\hline $1.6-2.0 \mathrm{ha}$ & $9(10.5)$ & \\
\hline $2.1-2.5$ ha & $1(1.2)$ & \\
\hline 2.6-3.0 ha & - & \\
\hline$>3.0$ ha & - & \\
\hline \multicolumn{3}{|l|}{ Access to credit } \\
\hline Yes & - & \\
\hline No & 86 & \\
\hline
\end{tabular}

Source: Field survey, 2016

Table 1 also indicates that the mean farm size of the respondents in the study area was 0.8 hectares which implies that majority of the respondents were in small-scale farming. The lesson to be drawn here is that, a situation where a large percentage of farmers have access only to small pockets of land does not promote agricultural production beyond subsistence level. This agrees with the findings of Musa $e t$ al., (2015) in Gombe State, Nigeria. All (100\%) the respondents did not have access to credit facilities in 2015/2016 cropping season, implying that the rice farmers in the study area used their personal savings as their major source of fund. This is in accord with Jamiu et al., (2016). This might hinder the adoption of UDP recommended practices in the State. According to Ndagi et al., (2016), lack 
of credit facilities limited the adoption of lowland rice technologies in Niger State, Nigeria.

The result of the regression model showed the factors influencing the adoption of UDP recommended practices in the study area as presented in Table 2. The regression result showed $\mathrm{R}^{2}$ value of 0.90 which implies that $90 \%$ variation in the adoption of UDP recommended practices in the study area was explained by the independent variables included in the model. The coefficient of sex was negatively related to the adoption of UDP recommended practices and statistically significant at $10 \%$. This is an indication that women rice farmers in the study area were more positively disposed to the use of UDP recommended practices. This result is in line with the findings of Omorogbee and Onemolease (2007) in Edo State, Nigeria where female Fadama farmers were more positively inclined to the use of recommended practices. The coefficient of household size was also positive and statistically significant at $10 \%$. This shows that as household size increased the probability of adoption of UDP recommended practices because the use of UDP recommended practices require additional labour from the rice farmers, which could be provided by household members. The finding agrees with the report Gasarah and Aye (2015) in Kwande Benue State, Nigeria.

Table.2: Factors influencing the adoption of UDP recommended practices

\begin{tabular}{lccc}
\hline Variables & Coefficient & Standard Error & T-value \\
\hline Sex & -0.895 & 2.263 & $-1.78^{*}$ \\
Age & -0.017 & 0.071 & -1.16 \\
Household size & 0.154 & 0.398 & $1.84^{*}$ \\
Education & 0.252 & 0.285 & $4.22^{* * *}$ \\
Rice farming experience & -0.021 & 0.055 & $-1.85^{*}$ \\
Farm size & 0.364 & 0.672 & $2.58^{* *}$ \\
Access to credit & $($ Omitted) & - & $($ Omitted) \\
Extension visit & 0.001 & 0.062 & 0.08 \\
Paddy output & 0.002 & 0.002 & $3.38^{* * *}$ \\
USG source & 0.815 & 3.070 & 1.26 \\
Training & 1.185 & 1.310 & $4.32^{* * *}$ \\
Affordability & 0.911 & 4.135 & 1.05 \\
Compatibility & 0.586 & 4.451 & 0.63 \\
Complexity & 3.008 & 2.209 & $6.48^{* * *}$ \\
Constant & 4.414 & 7.203 & $2.92^{* *}$ \\
\hline F-Value & & & 137.45 \\
R-squared & & & 0.90 \\
\hline
\end{tabular}

Source: Field survey, $2016 * * *=$ significant at $1 \%, * *=$ significant at $5 \%, *=$ significant at $10 \%$

Table 2 also reveals that the coefficient of education was positive and significant at $1 \%$. This indicates a positive relationship between respondents' education level and adoption of UDP recommended practices among the rice farmers in the study area. This finding corroborates that of Ehinmowo and Fatuase (2016) who reported significance influence of education on adoption of cassava processing technologies by women entrepreneurs into South-West, Nigeria. As against a priori expectation, the coefficient of number of years of farming experience by the farmers was negative and significant at $10 \%$. This signifies that the experience the rice farmers have gained over the years made it difficult for them to switch to UDP recommended rice practices, no matter the perceived benefits. This finding concurred with Ume and Ochiaka (2016) in Ebonyi State, Nigeria. A positive and significant relationship was found between rice farmers' farm size and adoption of UDP recommended rice practices with coefficient at 5\% probability level. Farmers with bigger farm size were better adopters, a result consistent with the findings of Kagbu et al., (2016), who found a positive and significant relationship between women rice farmers' farm size and adoption of recommended rice production practices in Nasarawa State, Nigeria.

Furthermore, the coefficient of paddy output was positive significant at 5\%. This implies that the output of the respondents increased with the adoption of UDP recommended practices. This agrees with Tsado (2013) who maintained that adoption of improved technology led to increased output of paddy rice in Niger and Kwara States, Nigeria. Likewise, training was positive and significant at $1 \%$ level of probability, indicating that training led to 
increase in adoption of UDP recommended practices among the rice farmers. This is line with Adjornon, and LiverpoolTasie (2014) who opined that training focused on a new technology to a specific group is likely to increase the adoption. In addition, the coefficient of complexity was positive and significant at $1 \%$ level of probability. This suggests that the more complex the UDP recommended practices, the more the farmers sought for alternative to the recommended practices. Complexity was also found to be positive and significant to the adoption of special rice project technology package by farmers under the rice value chain in Niger State, Nigeria by Mohammed et al., (2015).

Additionally, the null hypothesis which stated that "There is no significant relationship between the rice farmers' socioeconomic characteristics and the adoption of UDP recommended practices." was rejected because adoption was significantly affected by the rice farmers' sex, household size, education, rice farming experience and farm size.

Source: Field survey, 2016

Table.3: Constraints to adoption of UDP recommended practices

\begin{tabular}{lcc}
\hline Constraints & Percentage* & Rank \\
\hline Lack of credit facilities & 100.0 & $1^{\text {st }}$ \\
Line transplanting is labour intensive & 82.5 & $2^{\text {nd }}$ \\
Limited supply USG & 75.6 & $3^{\text {rd }}$ \\
USG application is time consuming & 75.6 & $3^{\text {rd }}$ \\
Inadequate training & 67.4 & $4^{\text {th }}$ \\
USG application is labour intensive & 60.4 & $5^{\text {th }}$ \\
Health Status & 58.2 & $6^{\text {th }}$ \\
Lack of improved rice seeds & 39.5 & $7^{\text {th }}$ \\
Nursery establishment is labour intensive & 34.9 & $8^{\text {th }}$ \\
\hline
\end{tabular}

*Multiple responses

Table 3 presents the result of constraints to adoption of UDP recommended practices by rice farmers in the study area. Lack of credit facilities (100.0\%), labourious nature of line transplanting (82.5\%), limited USG supply and time spent on application of USG (75.6\%) as well as inadequate training $(67.4 \%)$ were the major constraints to adoption of UDP recommended practices. Other constraints were the labourious nature of USG application (60.4\%), and the health status of the respondents (58.6\%). This result implies that the rice farmers were faced with myriads of constraints which limited their adoption of UDP recommended practices. The implication of lack of credit facilities could be that the rice farmers could not have the purchasing power for necessary farm inputs such as USG, which could reduce the level of adoption of UDP recommended practices among the rice farmers. Mustapha et al., (2012) found similar result in Borno State, Nigeria. Also, the laborious nature of USG application and transplanting as well as time spent during line transplanting and USG application deters the adoption of UDP recommended practices among the rice farmer in the study area. This agrees with Rahman and Barmon (2015), who reported that the utilization of UDP technology is labour intensive. Likewise, Tarfa and Kiger (2013) presented that that lack of access to USG is major problem hindering rice farmers from adopting UDP technology in Nigeria.
Additionally, Ajibola et al., (2015); Adesiji and Komolafe (2013) observed that good health affects agricultural activities by boosting farmer's capacity for intensive work and thus increases output.

\section{CONCLUSION AND RECOMMENDATIONS}

Adoption of UDP recommended practices was significantly influenced by sex, education, rice farming experience, farm size, paddy output, training and complexity. Constraints hindering adoption of UDP recommended practices were lack of credit facilities, labourious nature of line transplanting, limited USG supply, time spent on application of USG, inadequate training, the labourious nature of USG application and health status of the rice farmers were the major constraint to adoption of UDP recommended practices in the study area. Relevant agencies should make credit facilities accessible to rice farmers through removal of stringent conditions attached to credit assessment. Also, to better MARKETS II Nigeria Project UDP technology dissemination in the State, more trainings on UDP recommended practices should be a focal point for the government, NGOs, private sector actors. This will go a long way to improving the adoption of UDP recommended practices among the rice farmers. More so, the private sector actors that produce USG should develop a model that would make the input more accessible to rice 
farmers; this is strategic to improving the adoption of the UDP recommended practices in Niger State.

\section{REFERENCES}

[1] Adesiji, G.B. and Komolafe, S.E. 2013. Factor influencing the use of traditional healing among farmers in Kwara State, Nigeria. Albanian Journal Agricultural Science, 12(2), pp. 275-281

[2] Adjornon, S.G. and Liverpool-Tasie, L.S.O. (2014). Spatial Dependence in the Adoption of the Urea Deep Placement for Rice Production in Niger State, Nigeria: A Bayesian Spatial Autoregressive Probit Estimation Approach. Selected Paper prepared for presentation at the Agricultural and Applied Economics Association's 2014 AAEA Annual Meeting, Minneapolis, MN, July $27-29,2014$

[3] Ajibola, B.O., Komolafe, S.E. and Akangbe, J.A. (2015). Constraints faced by women vegetable farmers in Kwara State, Nigeria and its Agricultural Practices.Jordan of International Sciences, 11(4), pp.995-1006

[4] Chekene, M.B., and Chancellor, T.S.B. (2015). Factors affecting the adoption of improved rice Varieties in Borno State, Nigeria. J. Agric. Ext., 19(2), pp. 21-33

[5] Ehinmowo, O.O. and Fatuase, A.I. (20160. Adoption of improved cassava processing technologies by women entrepreneur in South - West, Nigeria. World Journal of Agricultural Research, 4(4), pp.109-113

[6] Fertilizer Suppliers Association of Nigeria (FEPSAN) (2014). FG approves Urea Super Granules inclusion in GES Scheme. Retrieved on April 3, 2015 from www.nationalmirroronline.net.

[7] Gasarah, F.H. and Aye, G.C. (2015). Effect of household endowment on fertilizer use in rice production in Kwande, Benue State, Nigeria. Asian Journal of Agricultural Extension, Economics and Sociology, 4(1), pp. 67-74

[8] International Fertilizer Development Center (IFDC). (2011). Urea Deep Placement: Hope for Food SelfSufficiency in West Africa September Press Release. [Online]: Available at: http://www.ifdc.org [August 15, 2015]

[9] International Fertilizer Development Center (IFDC). (2012). USAID/MARKETS II Urea Deep Placement (UDP) Technology Farmers Manual. pp. 3-12

[10] International Fertilizer Distribution Center (2013). International Fertilizer Distribution Center Projects in Nigeria. [Online]: Available at: http://www.ifdc.org/Nations/Nigeria [April 30, 2015]
[11] Jamiu, O. S., Muhammed, K., I. and Folashade, O. E. (2016). Socio-economic determinants of improved rice technologies' adoption among small scale farmers in Kogi State, Nigeria. Economics and Organization, 13(2), pp. $217-232$

[12] Kagbu, J. H., Omokore, D. F .and Akpoko, J. G. (2016). Adoption of recommended rice production practices among women rice farmers in Nasarawa State, Nigeria. Journal of Agricultural Extension, 20 (1), pp. 107-120

[13] Koloche, I.M., Olaleye, R.S., Adeniji, O.B., Yahaya S.A., Umar, S.I.M. and Tsado, J.H. (2016). Socioeconomic characteristics and constraints associated with the adoption of the improved shea nut processing technologies in Niger State, Nigeria. Greener Journal of Agricultural Sciences, 6 (1), pp. 001-009

[14] Mohammed, U., Olaleye, R. S., Umar, S., Ndanitsa, M. A. and Jibrin, S. (2015). An assessment of factors influencing adaptation of special rice project technology package by farmers under the rice value chain in Niger State, Nigeria. Asian Journal of Agricultural Extension, Economics and Sociology, 5(4), pp. 183-191

[15]Musa, H.Y., Umar, M.R. and Zakari, H. (2015). Assessment of Farmers Perception on Adoption of Improved Rice (Nerica) Recommended practices in Kwami Local Government Area of Gombe State, Nigeria Journal of Agriculture and Veterinary Sciences, 7(1), pp. 10-22

[16] Mustapha, S. B., Undiandeye, U. C., Sanusi, A. M.and Bakari, S. (2012). Analysis of adoption of improved rice production technologies in Jeer local government area of Borno State, Nigeria. International Journal of Development and Sustainability, 1(3), pp. 1112-1120

[17] Odoemenem, I. U. and Obinne, C. P. O. (2010). Assessing the factor influencing the utilization of improved cereal crop production technologies by smallscale farmers in Nigeria. Indian Journal of Science and Technology, 30, pp. 10-17

[18] Onyeneke, R. U. (2107). Determinants of Adoption of Improved Technologies in Rice Production in Imo State, Nigeria. African Journal of Agricultural Research, 12(11), pp. 888-896.

[19] Rahman, S. and Barmon, B.K. (2015). Productivity and efficiency impacts of urea deep placement technology in modern rice production: An empirical analysis from Bangladesh. The Journal of Developing Areas, 49 (3), pp. 119-134

[20] Tarfa, B. and Kiger, B. (2013). UDP and Rice production in Nigeria: The experience so far. At the Nigeria launch of 'Guiding Investments in Sustainable 
Agricultural Intensification in Africa (GISAIA)', Abuja.

June 17, 2013. (PowerPoint Presentation)

[21] Ume, S.I. and Ochiaka, J.S. (2016). Determinant factors to the adoption and discontinue adoption of improved okra (Abelmoschus Esculentus) production technologies in Ivo local government area of Ebonyi State, Nigeria. Case Studies Journal, 5(9), pp. 156-146

[22] Umeh, G.N. and Chuckwu, V.A. (2013). Determinant of adoption of improved rice production technologies in Ebonyi State, Nigeria. International. Journal of Food, Agriculture and Veterinary Science, 3(3) pp. 126 